\title{
Chinese Excellent Traditional Culture Study on the Path of Integrating the Ideological and Political Courses in Primary and Middle Schools
}

\author{
Shuwen Liu \\ College of Marxism, Jiangsu University, Zhenjiang 212013, Jiangsu Province, China
}

\begin{abstract}
Chinese excellent traditional culture contains the value pursuit of the Chinese nation, condenses the cultural consensus of the Chinese nation, and has rich connotation and connotation. At the moment of advocating the integration of ideological and political courses in primary and secondary schools, the integration of Chinese traditional culture into the curriculum content of ideological and political courses can have a subtle cultural impact on the students of different students, and help students to grow up physically and mentally and cultivate their ideology and morality. In order to achieve ideological and political curriculum implicit development.
\end{abstract}

Keywords: Traditional culture; Primary and secondary schools; Ideological and political courses; Curriculum content

Publication date: April, 2021; Publication online: 30 April, 2021

*Corresponding author: Shuwen Liu, 2914395017@qq.com

Chinese excellent traditional culture has a long history, extensive and profound, and has irreplaceable resource significance and ethical value for the reform of ideological and political education in the new period. At present, the integration reform and construction of ideological and political courses in primary and secondary schools has become a hot topic. It can fully reflect the creative consciousness and broad strategic vision of constructing ideological and political education system with Chinese characteristics and realize the innovation of ideological and political education in primary and secondary schools from the perspective of traditional culture.

\section{Necessity of the Integration of Chinese}

\section{Excellent Traditional Culture into Ideological}

\section{and Political Courses in Primary and Middle}

\section{Schools}

At present, the Central Committee attaches great importance to the construction of the integration of ideological and political courses in primary and secondary schools, and has held meetings many times to discuss the integration of primary and secondary schools. In order to implement the spirit of General Secretary Xi Jinping's important speech, many schools hold many academic research forums and teaching observation meetings. However, the reform of ideological and political courses in the new period is difficult. The current Chinese society is in the complicated social transition period, the social principal contradiction has taken place the huge transformation, this kind of transformation has caused the people life style, the value idea profound change. In the new period, students' physical and mental development has not yet matured, and their behavior habits and ways of thinking have also changed to a certain extent. Traditional culture is the education of students from childhood, students are born with a certain affinity to traditional culture, so it is necessary to actively absorb the essence of traditional culture and integrate traditional culture into the basic contents of ideological and political courses in primary and secondary schools.

\section{The significance of the integration of}

traditional culture into ideological and political courses in primary and secondary schools

2.1 It is conducive to the better realization of the educational goal of establishing morality and building people 
Ideological and political course is an organic whole with the whole process of youth growth and development. It is very important for the students who are not in the same school. Traditional culture representative books, such as Analects of Confucius, Laozi, University and the mean, contain not only a lot of philosophy, morality, wisdom, but also aphorisms that have enlightening effects on life, study and work. According to the characteristics of students' body and mind and the law of growth and development at different stages, selecting and applying appropriate traditional culture and combining with Xi Jinping's socialist thought with Chinese characteristics in the new era can promote the implicit development of ideological and political courses in the new era.

\subsection{It is beneficial to establish correct value orientation for students}

The integration of Chinese excellent traditional culture in the teaching of ideological and political courses in different learning sections is not only helpful to improve students' literary accomplishment and improve their physical and mental practice, but also to establish and establish scientific values. For example, "rise and fall of the country, equal responsibility "to help students from childhood to cultivate patriotic feelings and social responsibility; "the unity of nature and man" thought can make students understand the harmonious coexistence of man and nature; Confucian "benevolence" thought," do not do to others "and other ideas help students overcome self-centered shortcomings, infiltration of these spirits in the current process of ideological and political integration, can help students to establish a positive and progressive outlook on life.

\section{A Probe into the Way of Chinese Traditional}

\section{Culture Integrating into Ideological and \\ Political Courses in Primary and Middle}

\section{Schools}

\subsection{Teachers of ideological and political courses in different students should improve their comprehensive quality}

3.1.1 Can reasonably select and apply traditional culture in classroom teaching

As an ideological and political educator, we should master and understand certain traditional cultural connotations, have rich traditional cultural knowledge, and be able to reasonably select and use traditional cultural knowledge in different stages for teaching. At the same time in the process of communication with the object of education can use persuasive and rendering words to convince them. For example, in the primary school stage, students are in the formation of conduct, ideological and political teachers can use the "disciple rules" reading method, there are three, heart, heart, letter, read this, do not admire the other, this is not finished, do not rise "to regulate students' words and deeds, form good reading habits, lead them to" learn and learn, not to say "the joy of reading; In the middle school stage, students' outlook on life, values and world outlook are in the period of establishment, and they need correct value guidance urgently. Ideological and political teachers should actively use positive guidance such as" ambition in Dao, according to virtue, according to benevolence, wandering in art "," people do not believe, do not know what to do ", and pay attention to moral cultivation and conduct, which is always the root of ideological and political education.

\subsubsection{Can be consistent in classroom teaching}

Teachers should constantly improve themselves from teaching while "preaching, teaching and solving doubts ", teaching words and teaching simultaneously, consistent with words and deeds, realizing" teaching each other "and promoting self-cultivation in theory and practice. This will form a great appeal and appeal to the student union.

\subsubsection{Enrich my excellent knowledge of traditional culture} Chinese traditional culture is extensive and profound and rich in content. Teachers of ideological and political courses should fully grasp and understand the connotation of traditional culture, enhance their ability of self-analysis and research, research and observation, propaganda and expression, and carefully understand the rich connotation of traditional culture.

\subsection{Building a network of traditional culture and education in ideological and political courses in primary and secondary schools}

\subsubsection{Class is the main position}

Classroom is the main channel for students to receive ideological and political education and show the charm of Chinese excellent traditional culture at different stages of primary and secondary schools. In the ideological and political class of primary and secondary schools, we should effectively combine Chinese traditional culture with the current political hot spots and difficulties, and help students distinguish between good and evil with the help of traditional culture. In the course content of ideological and political course, we should introduce Chinese excellent traditional 
culture into teaching materials, introduce classroom, expand the excellent traditional culture education knowledge in ideological and political theory course of colleges and universities, and carry on teaching along the lines of persuasion, so that the ideological and political classroom knowledge and traditional cultural common sense can be absorbed into the mind. At the same time, teachers should actively change the teaching methods, fully apply modern educational technology, teach in fun, learn traditional virtues, and effectively realize the important role of traditional culture in ideological and political education. Schools and universities should also actively employ experts who are proficient in traditional culture to offer special lectures such as Zhouyi, Analects of Confucius and Zhuangzi, as well as elective courses such as introduction to Chinese Culture and interpretation of Tang and Song ci, so that students can fully feel the charm of Chinese traditional culture.

\subsubsection{Second class is an effective way}

Practice is very important for ideological and political courses in primary and secondary schools. No education can be separated from practice. While studying ideological and political courses and traditional culture courses, Schools should also pay attention to carrying out some practical activities with traditional cultural connotation and ideological and political education significance. These practical activities are not only the extension of ideological and political classroom theoretical knowledge, but also the deepening of traditional cultural education.

These practical activities can guide students to read classical literary works by inviting famous teachers and experts of "Chinese Studies ", organizing students to give speeches on an event in history, organizing the reading of Chinese classical American literature, or analyzing from the perspective of Chinese traditional culture philosophy according to the latest hot and difficult events. Outside the school, the school can also organize national conditions inspection, lead students to visit the educational significance of red tourist attractions, memorials, history museums and so on, to understand the humanistic spirit of Chinese traditional culture, enhance the national pride of college students; Actively organize students to participate in community practice and volunteer activities as volunteers and small journalists, which can improve students' political and moral quality.

\subsubsection{Internet is an important carrier}

The arrival of the media era has opened up a new educational vision and provided a new path and train of thought for the traditional education. The network has changed people's way of life and brought convenience to people's life. Colleges and universities must expand the traditional cultural and educational channels, make full use of the convenience of the network to open up the position of network education, build an educational platform on the network, and provide conditions for students to better accept ideological and political education.

In order to form the joint force of ideological and political education on the line and offline, schools should innovate the way of traditional culture communication, actively carry out lively network ideological and political education activities in combination with Chinese traditional culture. Set up the red website of ideological and political education on campus with characteristics and influence, break the limitation of time and space, turn the theory into audio and video to show students, so that students can be influenced by traditional culture in the process of imperceptible influence. At the same time, strengthen the purification of the network environment, the network is the information distribution center, all kinds of information is mixed, the physical and mental development of the students is at different levels, immature, easy to be misled, affecting the healthy growth of the students. Therefore, teachers of ideological and political courses in each section should master the network technology skillfully, guide the students in time, intervene the excellent traditional culture in the major thematic forums, discussion platforms, campus networks, and so on, so that the network can play a role in ideological and political education for college students.

\section{Conclusion}

In a word, Chinese excellent traditional culture has very important resource significance and ethical value for the development of the integration of ideological and political courses in primary and secondary schools. The thought of patriotism and collectivism, which is innovatively integrated into Chinese traditional culture, provides new methods and new ideas for ideological and political work in primary and secondary schools. The ideas, values and codes of conduct contained in Chinese traditional culture have become the essence of the integration of ideological and political education in primary and secondary schools. We should fully tap the ideological and political education resources in Chinese excellent traditional culture, take the spirit of 
Chinese excellent traditional culture as the sustenance, carry forward the national spirit, cultivate patriotic consciousness, integrate traditional culture into the ideological and political education of students in primary and secondary schools, and serve the ideological and political education of students in primary and secondary schools.
[1]Liu SY. An Inquiry into Chinese Excellent Traditional Culture and College Students' Ideological and Political Education[M]. Beijing: China Water Conservancy and Hydropower Press, China.

[2]Jiang JF. Cultural Self-consciousness: The Way of Traditional Culture Education for College Students[J]. School Party Building and ideological Education, 2008(11).

\section{References}

